\title{
Pengaruh Community Marketing Terhadap Loyalitas Pelanggan Pada Anggota Telkomsel School Commu- nity di Sekolah Menengah Atas dan Sederajat di Kota Bandung
}

Sri Nurani Puspa Dewi \& Heppy Millanyani

\section{ABSTRAK}

Saat ini persaingan perusahaan provider semakin ketat dari sebelumnya. Konsumen dengan mudah dapat berpindah dari satu operator ke operator lain sehingga perusahaan dituntut untuk mengubah konsumennya menjadi pelanggan yang loyal dengan membentuk komunitas. Begitupun dengan PT. Telkomsel yang membentuk komunitas, yaitu Telkomsel School Community. Dalam penelitian ini, terdapat variabel bebas yaitu community marketing yang terdiri dari empat sub variabel, yaitu membership, influence, integration and fulfillment of needs, dan shared emotional connections. Dan variabel terikat yaitu loyalitas pelanggan.Penelitian ini termasuk kedalam penelitian deskriptif dan kausal. Populasi dalam penelitian adalah seluruh anggota komunitas Telkomsel School Community di Sekolah Menengah Atas dan Sederajat di kota Bandung. Sampel yang terpilih adalah 90 responden dengan menggunakan teknik probability sampling melalui pendekatan simple random sampling. Analisis yang digunakan meliputi uji validitas, uji reliabilitas, analisis statistik deskriptif, uji asumsi klasik, analisis regresi linear berganda, dan uji hipotesis. Dari hasil analisis regresi linear berganda, diperoleh bahwa community marketing berpengaruh secara signifikan terhadap loyalitas pelanggan Telkomsel yang menjadi anggota komunitas Telkomsel School Community di Sekolah Menengah Atas dan Sederajat di kota Bandung sebesar 61,1\%. Dapat disimpulkan bahwa variabel community marketing berpengaruh secara signifikan terhadap loyalitas pelanggan. Dengan demikian PT. Telkomsel perlu mempertahankan elemen-elemen yang sudah dinilai baik dan perlu memperbaiki hal-hal yang masih kurang agar lebih mampu meningkatkan loyalitas pelanggan Telkomsel.

Kata kunci : Community Marketing, Loyalitas Pelanggan 


\section{Pendahuluan}

\section{JURNAL}

MANAJEMEN

INDONESIA

Vol. 14. No. 3

Desember 2014

\subsection{Latar Belakang Masalah}

Sebagai makhluk sosial manusia memiliki kebutuhan untuk saling berinteraksi antara satu individu dengan individu lainnya. Cara berkomunikasi yang sudah lama dikenal manusia adalah komunikasi tatap muka. Namun manusia memiliki mobilitas yang tinggi, sehingga komunikasi tidak bisa hanya bertatap muka saja. Oleh karena itu manusia memerlukan alat komunikasi yang dapat digunakan kapanpun dan dimanapun mereka berada, yaitu dengan menggunakan telepon genggam.

Manusia membutuhkan koneksi yang berkualitas untuk dapat terus melakukan komunikasi. Hal ini membuat banyak perusahaan operator seluler memproduksi kartu atau simcard. Saat ini di Indonesia terdapat lima operator seluler sebagai penyedia kartu GSM, hal ini menyebabkan persaingan yang ketat dalam merebut hati konsumen. Persaingan tersebut dapat terlihat dari Top Brand Index (TBI) pada tahun 2011 dan 2012 untuk simcard GSM Paskabayar sebagai berikut:

\begin{tabular}{|c|c|c|c|c|c|}
\hline No & Merek & TBI 2011 & No & Merek & TBI 2012 \\
\hline 1. & Kartu Halo & $66,2 \%$ & 1. & Kartu Halo & $71,0 \%$ \\
\hline 2. & Matrix & $15,7 \%$ & 2. & XL & $13,8 \%$ \\
\hline 3. & XL & $15,4 \%$ & 3. & Matrix & $12,6 \%$ \\
\hline
\end{tabular}

Pada tahun 2011 dan 2012, peringkat pertama Top Brand Index simcard GSM paskabayar yaitu Kartu Halo sebesar 66,2\% dan 71,0\%, diikuti oleh Matrix diperingkat kedua sebesar 15,7\% dan tahun 2012 berada di peringkat ketiga sebesar 12,6\%, dan diperingkat ketiga yaitu XL paskabayar sebesar 15,4\% dan tahun 2012 berada di peringkat kedua sebesar $13,8 \%$. Sama halnya untuk simcard GSM prabayar pada tahun 2011 dan 2012, produk Telkomsel tetap unggul. Berikut data selengkapnya:

\begin{tabular}{|c|c|c|c|c|c|}
\hline No & Merek & TBI 2011 & No & Merek & TBI 2012 \\
\hline 1. & Simpati & 48,0 & 1. & Simpati & 37,1 \\
\hline 2. & IM3 & 16,6 & 2. & IM3 & 17,8 \\
\hline 3. & XL prabayar & 14,8 & 3. & XL prabayar & 17,2 \\
\hline 4. & Kartu As & 9,9 & 4. & Kartu As & 10,9 \\
\hline 5. & Mentari & 7,3 & 5. & Mentari & 6,2 \\
\hline 6. & 3 (Three) & 1,8 & 6. & 3 (Three) & 5,9 \\
\hline 7. & Axis & 1,6 & 7. & Axis & 3,0 \\
\hline
\end{tabular}

Pada tahun 2011 dan 2012 Top Brand Index untuk simcard GSM Prabayar dikuasai oleh simPATI di peringkat pertama yaitu sebesar 48,0\% dan tahun 2012 turun menjadi 37,1\%, diikuti oleh IM3 di peringkat kedua sebesar 16,6\% dan tahun 2012 naik menjadi $17,8 \%$ dan XL prabayar diperingkat ketiga sebesar 14,8\% dan tahun 2012 naik menjadi 17,2 \%.

Menurut catatan survey yang dilakukan Mark Plus Insight, kualitas jaringan masih merupakan pertimbangan terpenting konsumen dalam memilih sebuah operator. Tidak mengherankan jika untuk simcard GSM Prabayar dan Paskabayar, simPATI dan Kartu Halo berhasil meraih peringkat pertama Top Brand Index dan terpopuler pilihan masyarakat karena kualitas jaringannya. Namun meskipun unggul kualitas jaringannya, produk Telkomsel untuk simcard GSM Prabayar yaitu simPATI cenderung mengalami penurunan dari 48\% menjadi 37.1\%. Hal ini terjadi karena, saat ini konsumen dengan mudah berpindah dari satu operator ke operator lain sehingga perusahaan dituntut untuk mengubah konsumennya menjadi pelanggan yang loyal. Salah satu cara 
adalah dengan membentuk komunitas. Begitupun dengan PT. Telkomsel yang merupakan operator telekomunikasi selular terbesar di Indonesia juga membentuk komunitas, diantaranya SimpatiZONE, Telkomsel Industry Community, Telkomsel Mobile Campus, dan Telkomsel School Community. Telkomsel School Community dibentuk untuk mempertahankan dan meningkatkan pangsa pasarnya dan menciptakan pelanggan yang loyal. Oleh karena itu, perlu dilakukan sebuah penelitian untuk menganalisis efektivitas program pemasaran berbasis komunitas (community marketing) dalam meningkatkan loyalitas pelanggan, khususnya pada program Telkomsel School Community di Sekolah Menengah Atas dan Sederajat di kota Bandung. Berdasarkan fenomena tersebut penulis tertarik untuk melakukan penelitian dengan judul "Pengaruh Community Marketing terhadap Loyalitas Pelanggan pada Telkomsel School Community di Sekolah Menengah Atas dan Sederajat di kota Bandung"

\subsection{Rumusan Masalah}

Berdasarkan hal tersebut, maka permasalahan yang akan diteliti adalah:

1.Bagaimana tanggapan anggota komunitas Telkomsel School Community di Sekolah Menengah Atas dan Sederajat di kota Bandung terhadap aktivitas community marketing yang telah dilakukan oleh PT. Telkomsel?

2. Bagaimana loyalitas pelanggan PT. Telkomsel yang menjadi anggota komunitas TelkomselSchoolCommunitydiSekolahMenengahAtasdanSederajatdikotaBandung?

3.Seberapa besar pengaruh community marketing terhadap loyalitas pelanggan Telkomsel yang menjadi anggota komunitas Telkomsel School Community di Sekolah Menengah Atas dan Sederajat di kota Bandung?

\subsection{Tujuan Penelitian}

Berdasarkan perumusan masalah diatas, tujuan dari penelitian ini adalah: 1.Mengetahui tanggapan anggota komunitas Telkomsel School Community di Sekolah Menengah Atas dan Sederajat di kota Bandung terhadap aktivitas community marketing yang telah dilakukan oleh PT. Telkomsel.

2. Mengetahui loyalitas pelanggan PT. Telkomsel yang menjadi anggota komunitas TelkomselSchoolCommunitydiSekolahMenengahAtasdanSederajatdikotaBandung.

3. Mengetahui seberapa besar pengaruh community marketing terhadap loyalitas pelanggan PT. Telkomsel yang menjadi anggota komunitas Telkomsel School Community di Sekolah Menengah Atas dan Sederajat di kota Bandung.

II. Tinjauan Pustaka dan Lingkup Penelitian

\subsection{Pengertian Community Marketing}

Rosenbaumetal(2005)mengutipMcMilian dan Chavisyangmenjelaskanbahwa suatuindividumencapairasakepuasandankesadarandalamberkomunitasketikamereka mendapat empat manfaat dari bergabung dengan kelompok tertentu. Manfaatini adalah:

a) Membership, adalah setiapanggotakelompokmemahamibahwamerekatelahmenginvestasikan bagian dari dirinya untuk menjadi anggota dalam suatu komunitas.

b) Influence, adalah sebuah kemampuan dari anggota komunitas untuk mempengaruhi komunitasnya serta merasakan bahwa komunitas juga bisa mempengaruhinya.

c) Integration and fulfillment of need, adalah suatu konsep yang mengacu pada anggota merasa dihargai jika dapat berpartisipasi di dalam kelompok.

d) Shared emotional connections, adalah suatu kepercayaan yang didapatkan para anggota komunitas untuk saling berbagi sejarah, pengalaman hidup yang sama, tempat-tempat, dan waktu bersama. Para pemasar mengambil kesempatan untuk menghancurkan dinding pemisah antara bisnis dan komunitas. Tujuannya adalah agar terbentuk hubungan kreatif yang saling memenuhi kebutuhan komunitas dan bisnis dengan membangun hubungan itulah yang disebut community marketing. 
JURNAL

MANAJEMEN

INDONESIA

Vol. 14. No. 3

Desember 2014
Karakteristik Loyalitas Pelanggan

Menurut Griffin (2005: 31), karakteristik pelanggan yang loyal adalah sebagai berikut:

1) Melakukan pembelian berulang secara teratur.

2) Membeli antarlini produk dan jasa.

3) Mereferensikan kepada orang lain.

4) Menunjukkan kekebalan terhadap tarikan para pesaing.

\section{Hubungan Community Marketing dengan Loyalitas Pelanggan}

Menurut Mc Alexander et al (2004: 25), kepuasan dan loyalitas terhadap produk atau jasa merupakan satu hal yang ingin dicapai dengan beberapa cara. Pertama, membentuk komunitas, komunitas dapat meningkatkan loyalitas dan komitmen pelanggan. Kedua, dengan adanya komunitas, pemasar juga akan mendapatkan feedback dari pengalaman pelanggan yang dapat menjadi masukan bagi pemasar untuk melakukan terobosan-terobosan baru dalam hal produk dan layanan. Ketiga, komunitas juga mampu membentuk sense of belonging atau rasa kepemilikan dalam benak pelanggan.

\subsection{Kerangka Pemikiran}

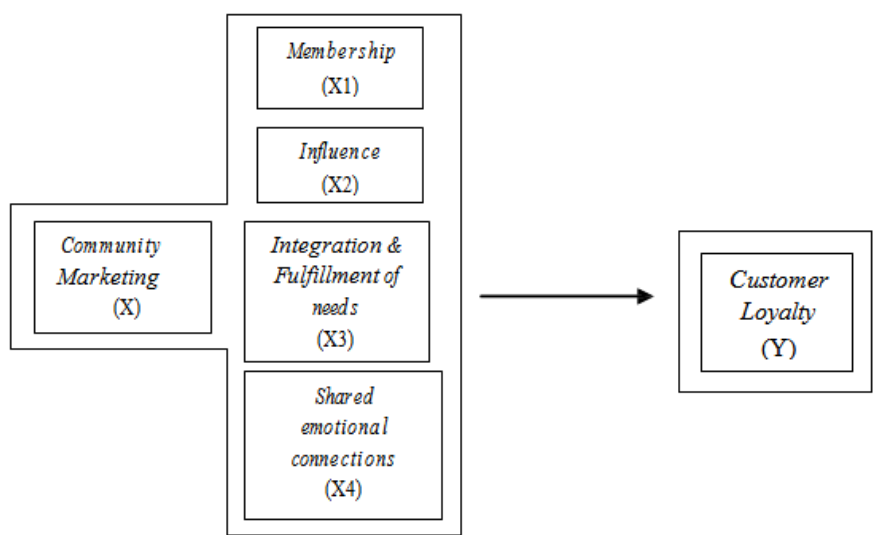

\section{Metode Penelitian}

\subsection{Jenis Penelitian}

Jenis penelitian ini termasuk kedalam jenis penelitian deskriptif dan kausal. Menurut Sugiyono (2011:11), penelitian deskriptif adalah penelitian yang dilakukan untuk mengetahui nilai variabel mandiri, baik satu variabel atau lebih tanpa membuat perbandingan. Sedangkan penelitian kausal merupakan penelitian yang bertujuan untuk mengetahui hubungan sebab akibat antara dua variabel atau lebih.

\subsection{Variabel Operasional}

Dalam penelitian ini terdiri atas dua jenis variabel, yaitu:

1. Variabel Bebas (Variabel X)

Menurut Sugiyono $(2011,39)$, variabel bebas merupakan variabel yang mempengaruhi atau yang menjadi sebab perubahannya atau timbulnya variabel terikat. Dalam penelitian ini variabel bebas adalah community marketing. Dengan empat sub variabel, yaitu membership, influence, integration and fulfillmentofneeds, dansharedemotional connections. 
Menurut Sugiyono $(2011,40)$, variabel terikat merupakan variabel yang menjadi akibat, karena adanya variabel bebas. Dalam penelitian ini variabel terikat adalah loyalitas pelanggan.

JURNAL

MANAJEMEN INDONESIA

Vol. 14. No. 3

Desember 2014

\subsection{Populasi dan Sampel Penelitian}

Populasi di dalam penelitian ini adalah anggota Telkomsel School Community di Sekolah Menengah Atas dan Sederajat di kota Bandung sebanyak 855 anggota. Dengan batas ketelitian 10\% diperoleh jumlah sampelnya adalah 90 responden. Teknik sampling adalah probability sampling. Menurut Sugiyono (2011: 91), probability sampling adalah teknik pengambilan sampel yang memberikan peluang yang sama bagi setiap unsur (anggota) populasi untuk dipilih menjadi anggota sampel. Dengan teknik probability sampling, digunakan simple random sampling. Simple random sampling adalah pengambilan anggota sampel dari populasi dilakukan secara acak (Sugiyono: 2011: 93).

\subsection{Uji Validitas dan Reliabilitas}

\subsubsection{Uji Validitas}

Uji validitas bertujuan untuk mengukur valid tidaknya suatu item pertanyaan. Nilai $r$ tabel untuk $n=30$ dengan taraf signifikansi $5 \%(\alpha=0,05)$ adalah 0,31 . Hasil uji validitas adalah sebagai berikut:

\begin{tabular}{|c|c|c|c|c|c|}
\hline \multicolumn{6}{|c|}{ Community Marketing (X) } \\
\hline Sub Variabel & No. Item & Indikator & r hitung & $r$ tabel & Ket. \\
\hline \multirow{3}{*}{ Membership } & C1 & Senantiasa berpartisipasi dalam komunitas & 0,562 & 0,31 & Valid \\
\hline & $\mathrm{C} 2$ & Mempunyai rasa memiliki terhadap komunitas & 0,545 & 0,31 & Valid \\
\hline & C3 & Mendapat manfaat saat bergabung dengan komunitas & 0,553 & 0,31 & Valid \\
\hline \multirow{3}{*}{ Influence } & $\mathrm{C} 4$ & Komunitas dapat mempengaruhi anggotanya & 0,630 & 0,31 & Valid \\
\hline & C5 & Sesama anggota dapat saling mempengaruhi & 0,581 & 0,31 & Valid \\
\hline & C6 & $\begin{array}{l}\text { Program komunitas memiliki kemampuan untuk } \\
\text { mempengaruhi perilaku pembelian }\end{array}$ & 0,583 & 0,31 & Valid \\
\hline \multirow{2}{*}{$\begin{array}{c}\text { Integration and } \\
\text { Fulfillment of } \\
\text { Needs }\end{array}$} & C7 & Merasa dihargai dan memiliki peran didalam komunitas & 0,562 & 0,31 & Valid \\
\hline & $\mathrm{C} 8$ & $\begin{array}{l}\text { Komunitas mampu menjadi sponsor dan dapat } \\
\text { memenuhi kebutuhan anggota }\end{array}$ & 0,641 & 0,31 & Valid \\
\hline \multirow{2}{*}{$\begin{array}{c}\text { Shared } \\
\text { Emotional } \\
\text { Connections }\end{array}$} & C9 & Komunitas sesuai dengan gaya hidup para anggotanya & 0,553 & 0,31 & Valid \\
\hline & C10 & $\begin{array}{l}\text { Mendapat pengalaman positif setelah berinteraksi } \\
\text { dengan anggota komunitas yang lain }\end{array}$ & 0,582 & 0,31 & Valid \\
\hline
\end{tabular}

\begin{tabular}{|c|l|c|c|c|}
\hline \multicolumn{3}{|c|}{ Loyalitas (Y) } \\
\hline $\begin{array}{c}\text { No. } \\
\text { Item }\end{array}$ & \multicolumn{1}{|c|}{ Indikator } & $r$ hitung & r tabel & Ket. \\
\hline D11 & Melakukan pembelian berulang & 0,734 & 0,31 & Valid \\
\hline D12 & Membeli antarlini produkdanjasa & 0,525 & 0,31 & Valid \\
\cline { 1 - 4 } D13 & & 0,621 & 0,31 & Valid \\
\hline D14 & Mereferensikan terhadap orang lain & 0,564 & 0,31 & Valid \\
\hline D15 & Menunjukkan kekebalanterhadap tarikan pesaing & 0,580 & 0,31 & Valid \\
\hline
\end{tabular}

Hasilnya adalah untuk semua pernyataan pada variabel community marketing dan variabel loyalitas hasilnya valid secara keseluruhan karena $\mathrm{r}$ hitung $>$ dari $\mathrm{r}$ tabel. 
Vol. 14. No. 3

Desember 2014

\begin{tabular}{|c|c|c|}
\hline Variabel & $\begin{array}{c}\text { Koefisien Reliabilitas } \\
\text { (Croanbach's Alpha) }\end{array}$ & Keterangan \\
\hline $\begin{array}{c}\text { Community Marketing } \\
(\mathrm{X})\end{array}$ & 0,865 & Reliabel \\
\hline Loyalitas (Y) & 0,812 & Reliabel \\
\hline
\end{tabular}

Berdasarkan tabel 3.5, dapat disimpulkan bahwa variabel community marketing (X) dan variabel loyaliyas (Y) memiliki kehandalan yang baik karena nilai Croanbach's Alpha $>0,60$.

\subsection{Teknik Analisis Data}

\section{Analisis Statistik Deskriptif}

Menurut Sugiyono (2011: 169), statistik deskriptif adalah statistik yang digunakan untuk menganalisis data dengan cara mendeskripsikan atau menggambarkan data yang telah terkumpul sebagaimana adanya tanpa bermaksud membuat kesimpulan yang berlaku untuk umum atau generalisasi.

2. Uji Asumsi Klasik

Uji asumsi klasik adalah pengujian asumsi-asumsi statistik yang harus dipenuhi pada analisis regresi linear berganda agar persamaan regresi yang diperoleh tidak bias dan konsisten. Terdiri dari:
a. Uji Normalitas
b. Uji Heteroskedastisitas
c. Uji Multikolinieritas
d. Uji Linieritas

\section{Analisis Regresi Linear Berganda}

\section{Uji Hipotesis}

a. Pengujian Hipotesis Secara Simultan (Uji F)

b. Pengujian Hipotesis Secara Parsial (Uji t)

c. Koefisien Determinasi

\section{Hasil Penelitian dan Pembahasan}

4.1 Karakteristik Responden

\subsubsection{Responden Berdasarkan Jenis Kelamin}

\begin{tabular}{|c|c|}
\hline Laki-Laki & $57 \%$ \\
\hline Perempuan & $43 \%$ \\
\hline
\end{tabular}

Jumlah responden berjenis kelamin laki-laki dan perempuan adalah sebesar $57 \%$ dan $43 \%$. Hal ini menunjukkan gambaran populasi dimana jumlah populasi laki-laki lebih banyak dari perempuan.

\subsubsection{Responden Berdasarkan Lama Bergabung dengan Komunitas}

\begin{tabular}{|c|c|}
\hline$<6$ bulan & $20 \%$ \\
\hline $6-12$ bulan & $58 \%$ \\
\hline$>12$ bulan & $22 \%$ \\
\hline
\end{tabular}


Berdasarkan lama bergabung dengan komunitas Telkomsel School Community, diketahuibahwa responden yang telah bergabung selama 6-12 sebesar $58 \%$. Haliniterjadi karena dalam populasi ternyatajumlah siswa/ siswiyang dudukdikelas 1 dankelas 2 SMA merupakan populasi terbanyak, sehingga mereka baru bergabung selama 6-12 bulan.

\subsubsection{Responden Berdasarkan Jenis Simcard Telkomsel yang Digunakan}

Vol. 14. No. 3

\begin{tabular}{|c|c|}
\hline simPATI & $50 \%$ \\
\hline Kartu AS & $50 \%$ \\
\hline
\end{tabular}

Desember 2014

RespondenyangmenggunakansimcardsimPATIdanKartuASadalahsebesar50\%

\subsection{Hasil Penelitian}

\subsubsection{Analisis Statistik Deskriptif}

UntukvariabelXyaitucommunitymarketingdiperolehnilaisebesar 76,58\%dapat disimpulkan bahwa tanggapan responden terhadap pelaksanaan aktifitas community marketing yang telah dilakukan oleh PT. Telkomsel memperoleh tanggapan yang baik. Untuk hasil analisis statistik deskriptif pada variabel $Y$ yaitu loyalitas pelanggan diperoleh nilai sebesar 76,61\% dengan demikian dapat disimpulkan bahwa loyalitas pelanggan PT. Telkomsel yang menjadi anggota komunitas Telkomsel School Community di Sekolah Menengah Atas dan Sederajat di kota Bandung masuk kedalam kategori baik.

\subsubsection{Uji Asumsi Klasik}

\section{a. Uji Normalitas}

Menurut Umar (2008: 181), uji normalitas untuk mengetahui apakah variabel dependen, independen atau keduanya berdistribusi normal atau tidak. Berikut hasil dengan analisis grafik:

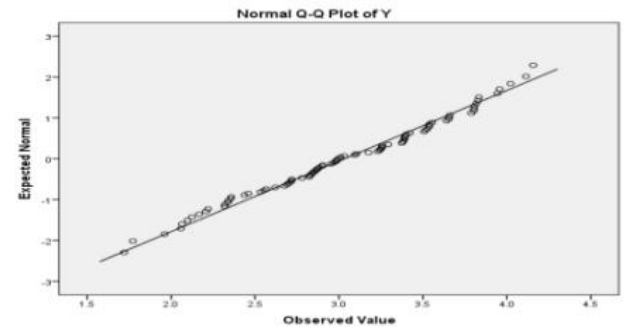

Hasilmya titik-titik menyebar di sekitar garis diagonal hal ini menunjukkan bahwa model regresi dapat dikatakan berdistribusi normal. Untuk uji normalitas berdasarkan analisis statitistik adalah:

Tests of Normality

\begin{tabular}{|l|r|r|r|r|r|c|}
\hline & \multicolumn{3}{|c|}{ Kolmogorov-Smirnov $^{\mathrm{a}}$} & \multicolumn{3}{c|}{ Shapiro-Wilk } \\
\cline { 2 - 7 } & Statistic & \multicolumn{1}{c|}{$\mathrm{df}$} & \multicolumn{1}{c|}{ Sig. } & Statistic & \multicolumn{1}{c|}{ df } & \multicolumn{1}{c|}{ Sig. } \\
\hline $\mathrm{Y}$ & .078 & 90 & .200 & .982 & 90 & .257 \\
\hline
\end{tabular}

Berdasarkan hasil uji nomalitas dengan menggunakan uji statistik, diketahui nilai signifikansi Kolmogorov-Smirnov adalah $0,200>0,05$. Dapat disimpulkan bahwa data berdistribusi normal. 
JURNAL

MANAJEMEN

INDONESIA

Vol. 14. No. 3

Desember 2014

\section{b. Uji Heteroskedastisitas}

Menurut Wijaya dalam Sarjono dan Julianita (2011: 66), heteroskedastisitas menunjukkan bahwa varians variabel tidak sama untuk semua pengamatan. Berikut hasil melalui analisis grafik:

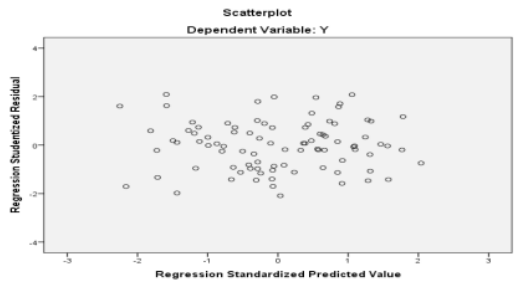

Hasil uji grafik menunjukkan bahwa distribusi data tidak membentuk pola-pola tertentu pada scatterplot. Dapat disimpulkan bahwa model regresi tidak mengandung heteroskedastisitas. Sedangkan analisis statistik yang digunakan adalah uji Glejser sebagai berikut:

\begin{tabular}{|c|c|c|c|c|c|c|}
\hline \multirow{2}{*}{\multicolumn{2}{|c|}{ Model }} & \multicolumn{2}{|c|}{ Unstandardized Coefficients } & \multirow{2}{*}{$\begin{array}{c}\begin{array}{c}\text { Standardized } \\
\text { Coefficients }\end{array} \\
\text { Beta } \\
\end{array}$} & \multirow[b]{2}{*}{$t$} & \multirow[b]{2}{*}{ Sig. } \\
\hline & & $\mathrm{B}$ & Std. Error & & & \\
\hline \multirow[t]{5}{*}{1} & (Constant) & .410 & .130 & & 3.160 & .002 \\
\hline & $\mathrm{X} 1$ & .057 & .053 & .168 & 1.089 & .279 \\
\hline & $x_{2}$ & -.050 & .055 & -.145 & -.909 & .366 \\
\hline & $\mathrm{X} 3$ & -.029 & .044 & -.097 & -.661 & .510 \\
\hline & $\mathrm{X}_{4}$ & -.011 & .044 & -.037 & -.256 & .799 \\
\hline
\end{tabular}

Diketahui bahwa nilai probabilitas signifikasi untuk masing-masing sub variabel X1, X2, X3, X4 adalah lebih besar dari 0,05. Jadi model regresi tidak terdapat gejala heteroskedastisitas.

\section{c. Uji Multikolinieritas}

Bertujuan untuk mengetahui apakah hubungan di antara variabel bebas memiliki masalah multikorelasi (gejala multikolinieritas) atau tidak. Hasil uji multikolinearitas adalah sebagai berikut:

\section{Coefficients $^{\mathrm{a}}$}

\begin{tabular}{|ll|r|r|}
\hline \multirow{2}{*}{ Model } & \multicolumn{2}{|c|}{ Collinearity Statistics } \\
\cline { 3 - 4 } & & Tolerance & \multicolumn{1}{c|}{ VIF } \\
\hline 1 & X1 & .479 & 2.089 \\
& X2 & .446 & 2.240 \\
& X3 & .528 & 1.892 \\
& X4 & .540 & 1.853 \\
\hline
\end{tabular}

a. Dependent Variable: $Y$

Diketahui bahwa nilai VIF (variance-inflating factor) pada masing-masing sub variabel bebas < 10, dapat disimpulkan bahwa tidak terjadi gejala multikolinieritas di antara sub variabel bebas.

\section{d. Uji Linieritas}

Menurut Sarjono dan Julianita (2011: 74), pengujian linieritas bertujuan untuk mengetahui apakah data yang kita miliki sesuai dengan garis linier atau tidak. 
1) Hasil Uji Linieritas Sub Variabel Membership (X1) terhadap Loyalitas (Y)

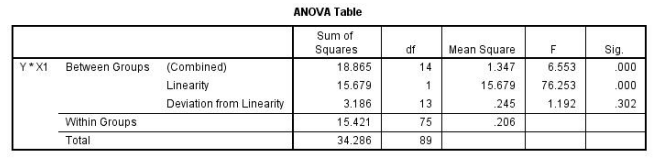

JURNAL

MANAJEMEN

INDONESIA

Vol. 14. No. 3

Desember 2014

Nilai signifikansi sub variabel X1 adalah 0,302 > 0,05. Jadi hubungan antar variabel bersifat linier

2) Hasil Uji Linieritas Sub Variabel Influence (X2) terhadap Loyalitas (Y)

\begin{tabular}{|c|c|c|c|c|c|c|c|}
\hline & & & & & & & \\
\hline & & & $\begin{array}{l}\text { Sum of } \\
\text { Squares }\end{array}$ & df & Mean Square & $F$ & Sig. \\
\hline \multirow[t]{5}{*}{$\gamma * X_{2}$} & Between Groups & (Combined) & 22.468 & 22 & 1.021 & 5.790 & .000 \\
\hline & & Linearity & 16.987 & 1 & 16.987 & 96.305 & .000 \\
\hline & & Deviation from Linearity & 5.481 & 21 & .261 & 1.480 & .115 \\
\hline & Within Groups & & 11.818 & 67 & .176 & & \\
\hline & Total & & 34.286 & 89 & & & \\
\hline
\end{tabular}

Nilai signifikansi sub variabel X2 adalah $0,115>0,05$. Jadi hubungan antar variabel bersifat linier

3) Uji Linieritas Variabel Integration and Fulfillment of Needs (X3) terhadap Loyalitas $(\mathrm{Y})$

\begin{tabular}{|c|c|c|c|c|c|c|c|}
\hline \multicolumn{8}{|c|}{ ANOVA Table } \\
\hline & & & $\begin{array}{l}\text { Sum or } \\
\text { Squares }\end{array}$ & df & Mean Square & $\mathrm{F}$ & Sig. \\
\hline \multirow[t]{5}{*}{$y * \times 3$} & Between Groups & (Combined) & 14.770 & 11 & 1.343 & 5.366 & .000 \\
\hline & & Linearity & 13.085 & 1 & 13.085 & 52.296 & .000 \\
\hline & & Deviation from Linearity & 1.684 & 10 & .168 & .673 & .746 \\
\hline & Within Groups & & 19.517 & 78 & .250 & & \\
\hline & Total & & 34.286 & 89 & & & \\
\hline
\end{tabular}

Nilai signifikansi sub variabel X3 adalah $0,746>0,05$. Jadi hubungan antar variabel bersifat linier.

4) Uji Linieritas Variabel Shared Emotional Connections (X4) terhadap Loyalitas (Y)

\begin{tabular}{|c|c|c|c|c|c|c|c|}
\hline \multicolumn{8}{|c|}{ ANOVA Table } \\
\hline & & & $\begin{array}{l}\text { Sum of } \\
\text { Squares }\end{array}$ & df & Mean Square & $\mathrm{F}$ & Sig. \\
\hline \multirow[t]{5}{*}{$\gamma^{*} \times 4$} & Bewween Groups & (Combined) & 22.407 & $B$ & 2.801 & 19.098 & .000 \\
\hline & & Linearity & 21.005 & 1 & 21.005 & 143.227 & .000 \\
\hline & & Deviation from Linearit/ & 1.402 & 7 & .200 & 1.365 & .231 \\
\hline & Within Groups & & 11.879 & 81 & .147 & & \\
\hline & Total & & 34.286 & 89 & & & \\
\hline
\end{tabular}

Nilai signifikansi sub variabel X4 adalah 0,231 >0,05. Jadi hubungan antar variabel bersifat linier.

\subsubsection{Analisis Regresi Linear Berganda}

Menurut Sarjono dan Julianita (2011: 91), analisis regresi adalah suatu analisis yang digunakan untuk mengukur pengaruh variabel bebas terhadap variabel terikat.

\begin{tabular}{|c|c|c|c|c|c|c|}
\hline \multicolumn{7}{|c|}{ Coefficients $^{a}$} \\
\hline \multirow{2}{*}{\multicolumn{2}{|c|}{ Model }} & \multicolumn{2}{|c|}{ Unstandardized Coefficients } & \multirow{2}{*}{$\begin{array}{c}\begin{array}{c}\text { Standardized } \\
\text { Coefficients }\end{array} \\
\text { Beta } \\
\end{array}$} & \multirow[b]{2}{*}{$\mathrm{t}$} & \multirow[b]{2}{*}{ Sig. } \\
\hline & & $\mathrm{B}$ & Std. Error & & & \\
\hline 1 & (Constant) & .374 & .223 & & 1.678 & .097 \\
\hline & $\mathrm{X} 1$ & .235 & .091 & .247 & 2.589 & .011 \\
\hline & $\mathrm{x} 2$ & .297 & .094 & .313 & 3.166 & .002 \\
\hline & X3 & .131 & .076 & .157 & 1.723 & .089 \\
\hline & $\times 4$ & .187 & .075 & .224 & 2.486 & .015 \\
\hline
\end{tabular}


Persamaan Regresi Linear Berganda

JURNAL

MANAJEMEN

$\mathrm{Y}=\mathrm{a}+\mathrm{b} 1 \mathrm{X} 1+\mathrm{b} 2 \mathrm{X} 2+\mathrm{b} 3 \mathrm{X} 3+\mathrm{b} 4 \mathrm{X} 4$

INDONESIA

$\mathrm{Y}=0,374+0,235 \mathrm{X} 1+0,297 \mathrm{X} 2+0,131 \mathrm{X} 3+0,187 \mathrm{X} 4$

Vol. 14. No. 3

Koefisien regresi pada variabel Membership memiliki pengaruh positif un-

Desember 2014 tuk menciptakan loyalitas pelanggan, atau dapat disimpulkan bahwa setiap peningkatan Membership sebesar satu satuan maka akan meningkatkan loyalitas pelanggan sebesar 0,235 kali lipat. Koefisien regresi pada variabel Influence memiliki pengaruh positif untuk menciptakan loyalitas pelanggan, dengan kata lain setiap peningkatan Influence sebesar satu satuan maka akan meningkatkan loyalitas pelanggan sebesar 0,297 kali lipat. Koefisien regresi pada sub variabel Integration and Fulfillment of Needs nilai signifikansinya sebesar 0,089 > 0,05 maka Integration and Fulfillment of Needs tidak signifikan dalam mempengaruhi loyalitas pelanggan. Koefisien regresi pada variabel Shared Emotional Connections memiliki pengaruh positif untuk menciptakan loyalitas pelanggan, atau dapat dikatakan bahwa setiap peningkatan Shared Emotional Connections sebesar satu satuan maka akan meningkatkan loyalitas pelanggan sebesar 0,187 kali lipat.

\subsubsection{Uji Hipotesis}

a. Pengujian Hipotesis Secara Simultan (Uji F)

Menurut Sarjono dan Julianita (2011: 106), uji F berguna untuk mengetahui semua variabel bebas yang berpengaruh terhadap variabel terikat. Adapun hipotesis yang diajukan adalah sebagai berikut:

H0 : Community marketing tidak berpengaruh secara signifikan terhadap loyalitas pelanggan pada anggota Telkomsel School Community.

H1 : Community marketing berpengaruh secara signifikan terhadap loyalitas pelanggan pada anggota Telkomsel School Community.

Hasil uji F adalah sebagai berikut:

ANOVA $^{a}$

\begin{tabular}{|ll|r|r|r|r|r|}
\hline Model & & $\begin{array}{c}\text { Sum of } \\
\text { Squares }\end{array}$ & df & Mean Square & F & Sig. \\
\hline 1 & Regression & 21.547 & 4 & 5.387 & 35.943 & $.000^{\circ}$ \\
& Residual & 12.739 & 85 & .150 & & \\
& Total & 34.286 & 89 & & & \\
\hline
\end{tabular}

a. Dependent Variable: $Y$

b. Predictors: (Constant), X4, X3, X1, X2

Nilai signifikansi $\mathrm{F}$ adalah $0,000<0,05$ oleh karena itu $\mathrm{H} 0$ ditolak. Dengan demikian keempat sub variabel bebas yaitu, Membership,Influence,Integration and fillment of Needs, dan Shared Emotional Connections berpengaruh secara signifikan terhadap loyalitas pelanggan.

\section{b. Pengujian Hipotesis Secara Parsial (Uji t)}

Uji t digunakan untuk mengetahui variabel mana yang relatif lebih dominan mempengaruhi loyalitas pelanggan (Priyatno, 2012: 92).

H0 : Membership, Influence, Intregration and Fulfillment of Needs, Shared Emotional Connections tidak berpengaruh secara signifikan terhadap loyalitas pelanggan pada anggota Telkomsel School Community. 

Connections berpengaruh secara signifikan terhadap loyalitas pelanggan pada anggota Telkomsel School Community.

Hasil uji t adalah sebagai berikut:

\begin{tabular}{|c|c|c|c|c|c|c|}
\hline \multicolumn{7}{|c|}{ Coefficients $^{a}$} \\
\hline \multirow[b]{2}{*}{ Model } & & \multicolumn{2}{|c|}{ Unstandardized Coefficients } & \multirow{2}{*}{$\begin{array}{c}\text { Standardized } \\
\text { Coefficients } \\
\text { Beta }\end{array}$} & \multirow[b]{2}{*}{$t$} & \multirow[b]{2}{*}{ Sig. } \\
\hline & & $B$ & Std. Error & & & \\
\hline 1 & (Constant) & .374 & .223 & & 1.678 & .097 \\
\hline & $\mathrm{x} 1$ & .235 & .091 & .247 & 2.589 & .011 \\
\hline & $\times 2$ & .297 & .094 & .313 & 3.166 & .002 \\
\hline & X3 & .131 & .076 & .157 & 1.723 & .089 \\
\hline & $\times 4$ & .187 & .075 & .224 & 2.486 & .015 \\
\hline
\end{tabular}

a. Dependent Variable: $Y$

\section{a) Membership (X1)}

Diketahui bahwa variabel Membership, Influence, dan Shared Emotional Connections memiliki pengaruh sebesar 24,7\%,31,3\%, dan 22,4\% terhadap loyalitas pelanggan. Dengan taraf signifikansi t untuk sub variabel Membership sebesar 0,011 $<0,05$, Influence sebesar 0,002 <0,05, dan Shared Emotional Connections sebesar $0,015<0,05$ dapat disimpulkan bahwa H0 ditolak yang berarti variabel Membership, Influence, dan Shared Emotional Connections berpengaruh secara signifikan terhadap loyalitas pelanggan pada anggota Telkomsel School Community. Sedangkan sub variabel Integration and Fulfillment of Needs nilai taraf signifikansi t sebesar $0,089>0,05$ yang berarti bahwa H0 diterima. Sub variabel Integration and fulfillment of needs tidak berpengaruh secara signifikan terhadap loyalitas pelanggan pada anggota Telkomsel School Community.

\section{c. Koefisien Determinasi}

Menurut Ghozali (2012: 97), untuk mengukur seberapa jauh kemampuan model dalam menerangkan variasi variabel dependen. Dilihat pada nilai adjusted R2 untuk mengetahui besarnya pengaruh variabel $\mathrm{X}$ secara simultan terhadap variabel $\mathrm{Y}$. Berikut adalah hasil pengujian koefisien determinasi:

Model Summary
\begin{tabular}{|l|c|r|r|r|}
\hline Model & R & R Square & $\begin{array}{c}\text { Adjusted R } \\
\text { Square }\end{array}$ & $\begin{array}{c}\text { Std. Error of } \\
\text { the Estimate }\end{array}$ \\
\hline 1 & $.793^{\text {a }}$ & .628 & .611 & .38713 \\
\hline
\end{tabular}
a. Predictors: (Constant), X4, X3, X1, X2
b. Dependent Variable: $Y$

Nilai Adjusted R Square adalah sebesar 0,611. Hal ini berarti secara simultan variabel Community Marketing (X) berpengaruh secara signifikan terhadap variabel Loyalitas pelanggan (Y) sebesar $61,1 \%$ dan sisanya 38,9\% dipengaruhi oleh variabel lain yang tidak digunakan dalam penelitian ini. 
JURNAL

MANAJEMEN

INDONESIA

Vol. 14. No. 3

Desember 2014
KESIMPULAN DAN SARAN

\subsection{Kesimpulan}

Berdasarkan hasil penelitian yang telah diuraikan, maka dapat ditarik kesimpulan dari penelitian ini, yaitu sebagai berikut:

1. Tanggapan responden yang merupakan anggota komunitas Telkomsel School Community di Sekolah Menengah Atasdan Sederajat di kota Bandung terhadap aktifitas community marketing yang telah dilakukan oleh PT. Telkomsel adalah sebesar 76,58\% dan berada dalam kategori baik.

2. Loyalitas pelanggan PT. Telkomsel yang menjadi anggota Telkomsel School Community di Sekolah Menengah Atas dan Sederajat di kota Bandung memperoleh persentase nilai sebesar $76,61 \%$ dan masuk dalam kategori baik.

3. Secara simultan community marketing berpengaruh signifikan terhadap loyalitas pelanggan yaitu sebesar $61,1 \%$. Sedangkan sisanya sebesar $38,9 \%$ dipengaruhi oleh variabel lain yang tidak digunakan dalam penelitian ini. Secara parsial sub variabel Membership memiliki pengaruh yang signifikan terhadap loyalitas pelanggan yaitu sebesar $24,7 \%$. Sub variabel Influence memiliki pengaruh yang signifikan terhadap loyalitas pelanggan yaitu sebesar 31,3\%. Dan sub variabel Shared Emotional Connections memiliki pengaruh yang signifikan terhadap loyalitas pelanggan yaitu sebesar 22,4\%. Sedangkan sub variabel Integration and Fulfillment of Need tidak memiliki pengaruh yang signifikan terhadap loyalitas pelanggan.

\subsection{Saran}

\subsubsection{Saran Untuk Perusahaan}

Dari kesimpulan dapat terlihat bahwa aktifitas community marketing yang telah dilakukan oleh PT. Telkomsel berada dalam kategori baik, begitupun loyalitas pelanggan PT. Telkomsel yang menjadi anggota Telkomsel School Community di Sekolah Menengah Atas dan Sederajat di kota Bandung berada dalam kategori baik. Oleh karena itu, diharapkan PT. Telkomsel tetap menjaga komunitas tersebut dengan lebih baik lagi.

Pengaruh variabel community marketing terhadap loyalitas pelanggan sudah signifikan. Terutama untuk sub variabel Influence yang memiliki pengaruh terbesar terhadap loyalitas pelanggan, dimana sub variabel Influence ini membuktikan bahwa komunitas dapat mempengaruhi anggota dan para anggota dapat saling mempengaruhi satu sama dalam pembelian produk Telkomsel lainnya. Untuk sub variabel Membership, pengaruhnya dapat ditingkatkan dengan cara memberi harga khusus pada anggota Telkomsel School Community untuk menggunakan modem TelkomselFLASH. Untuk sub variabel Shared Emotional Connections dapat ditingkatkan dengan cara memperbanyak aktifitas yang dapat mempertemukan seluruh anggota komunitas Telkomsel School Community. Serta untuk sub variabel yang tidak memiliki pengaruh yang signifikan yaitu Integration and Fulfillment of Needs dapat diperbaiki dengan cara mengadakan event-event yang pelaksanaannya dikelola oleh para anggota komunitas Telkomsel School Community sehingga para anggota komunitas dapat memiliki peran di dalam komunitas Telkomsel School Community di Sekolah Menengah Atas dan Sederajat di kota Bandung. 


\subsubsection{Saran Untuk Penelitian Selanjutnya}

Untuk penelitian selanjutnya dengan topik yang sama, disarankan untuk menambah jumlah sampel dengan batas ketelitian yang lebih kecil dengan metodologi penelitian dan objek penelitian yang berbeda. Atau disarankan untuk penelitian selanjutnya meneliti bagian lain pada new wave marketing.

\section{DAFTAR PUSTAKA}

Ghozali,Imam. 2012. Aplikasi Analisis Multivariate Dengan Program IBM SPSS 20. Semarang: Badan Penerbit Universitas Diponegoro.

Griffin, Jill. 2005. Customer Loyalty: Menumbuhkan dan Mempertahankan Kesetiaan Pelanggan. Edisi Revisi dan Terbaru. Jakarta: Erlangga.

Kertajaya, Hermawan et.al. 2003. Marketing in Venus. Jakarta: PT. Gramedia Pustaka Utama.

Kertajaya, Hermawan., dan Darwin, Waizly. 2010. Connect Surfing New Wave Marketing. Jakarta: PT. Gramedia Pustaka Utama.

Kertajaya, Hermawan. 2009. New Wave Marketing: The World is Still Round The Market is Already Flat. Cetakan Kedua. Jakarta: PT. Gramedia Pustaka Utama.

Mulyatiningsih, Endang. 2012. Metode Penelitian Terapan Bidang Pendidikan. Cetakan Kesatu. Bandung: CV. Alfabeta.

Priyatno, Duwi. 2012. Cara Kilat Belajar Analisis Data dengan SPSS 20. Yogyakarta: CV. Andi Offset

Riduwan. 2010. Metode dan Teknik Menyusun Tesis. Bandung: CV. Alfabeta

Sarjono, Haryadi., dan Winda Julianita. 2011. SPSS vs Lisrel: Sebuah Pengantar, Aplikasi untuk Riset. Jakarta: Penerbit Salemba Empat.

Sugiyono. 2012. Metode Penelitian Administrasi Dilengkapi dengan Metode R\&D. Bandung: CV. Alfabeta. Umar, Husein. 2008. Metode Penelitian untuk Skripsi dan Tesis Bisnis. Edisi Kedua. Jakarta: PT. Raja Grafindo Persada.

Yuswohady. 2008. CROWD Marketing Becomes Horizontal. Jakarta: PT. Gramedia Pustaka Utama. 
JURNAL

MANAJEMEN

INDONESIA

Vol. 14. No. 3

Desember 2014 